九州大学学術情報リポジトリ

Kyushu University Institutional Repository

\title{
Evaluation of Green Paradox: Case Study of Japan
}

Fuj isaki, Takaya

Kyushu University Interdisciplinary Graduate School of Engineering Sciences

https://doi.org/10.5109/2174855

出版情報 : Evergreen. 5 (4)，pp. 26-31，2018-12. 九州大学グリーンアジア国際リーダー教育センター バージョン：

権利関係 : 


\title{
Evaluation of Green Paradox: Case Study of Japan
}

\author{
Takaya Fujisaki \\ Kyushu University Interdisciplinary Graduate School of Engineering Sciences, Japan
}

*Author to whom correspondence should be addressed, E-mail: takaya.fujisaki.328@s.kyushu-u.ac.jp

(Received October 17, 2018; accepted December 25, 2018).

\begin{abstract}
Introducing renewable energy is progressing rapidly in various countries. It has long been thought that the introducing is not only extending the availability period of fossil fuels but also not directly discharging harmful substances into the atmosphere. In recent years, a concept of "Green Paradox" casts doubt on that ideas. According to the concept, the renewable energy introducing accelerates fossil fuels consumption and promotes the increase of harmful substances due to the consumption. Because the number of papers evaluating the Green Paradox is limited and evaluation method is not well established. This paper attempts to evaluate the Green Paradox in Japan following three indicators. The first is the electricity charge, the second is the introduction amount of renewable energy, and the third is the relocation amount of Japanese factories to other countries.
\end{abstract}

Keywords: Renewable energy, Green Paradox, Japan, fossil fuels hydrogen energy

\section{Introduction}

Our society has consumed fossil fuels and generated electricity to promote our economic growth. The amount of natural gas, coal/petroleum, and oil consumption known for typical fossil fuels accounted for over $80 \%$ shown in Fig. $1^{1}$. The amount of consumption is estimated to keep growing up as shown in Fig $2^{2}$. When we take into account of the mining limitation, minable years as reserves-to-production $(\mathrm{R} / \mathrm{P})$ rate tends to decrease $\mathrm{e}^{3}$. Although natural gas could keep supporting the demand of our society near future, the minable years will face the limitation in the long term.

Although the fossil fuels will be exhausted in the future, we could afford to keep consuming for several hundred years. However, what we have to consider is not the year when fossil fuels dried up, but when fossil fuels are mined with the largest amount. As long as we no longer increase the amount of mined fossil fuels, the economic growth will not be maintained because our society relays on the fossil fuels. Mohr et.al. suggest that the year when the amount of fossil fuels becomes the most so-called "production peak" of primary fossil fuels will come by $2025^{4}$. Although the estimation is significantly earlier than reality, we will not be able to avoid the production peak in the future. Our economy is relying on the fossil fuels. Before the production peak comes, we need to build society which does not relay on fossil fuels. Otherwise our social situation depending on them will be very unstable.

It seems introducing renewable energy with solar power and wind power is the promising way for our future. The renewable energy does not directly emit harmful substance such as $\mathrm{CO}_{2}$ which could lead to global warming 5 . Indeed, hydropower as a renewable energy could be increased to supply electricity in the future. ${ }^{6}$ However, the amount will not be able to cover total energy demand for future due to the limited location for new installation sites.

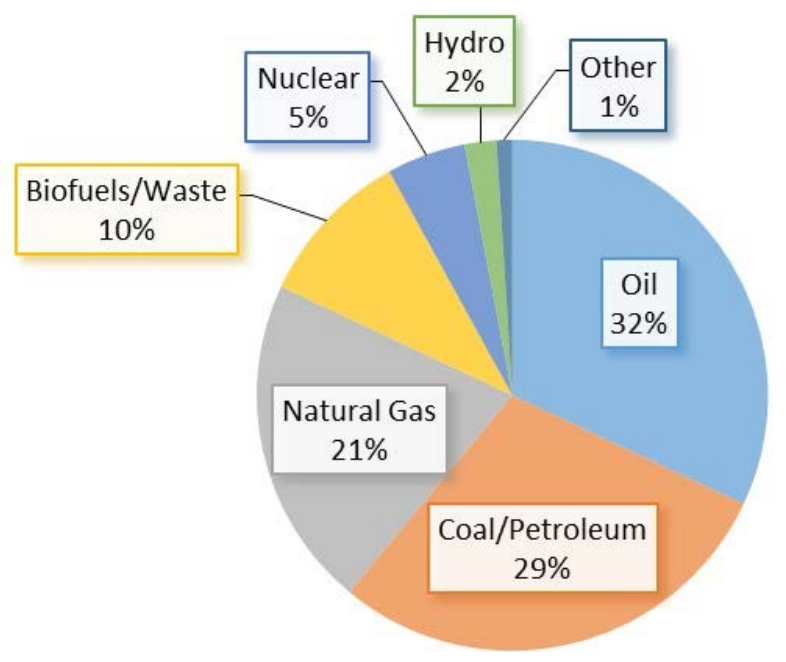

Fig. 1: World's fuel shares of total primary energy supply. ${ }^{1}$ 
roadmap which is composed of three steps.

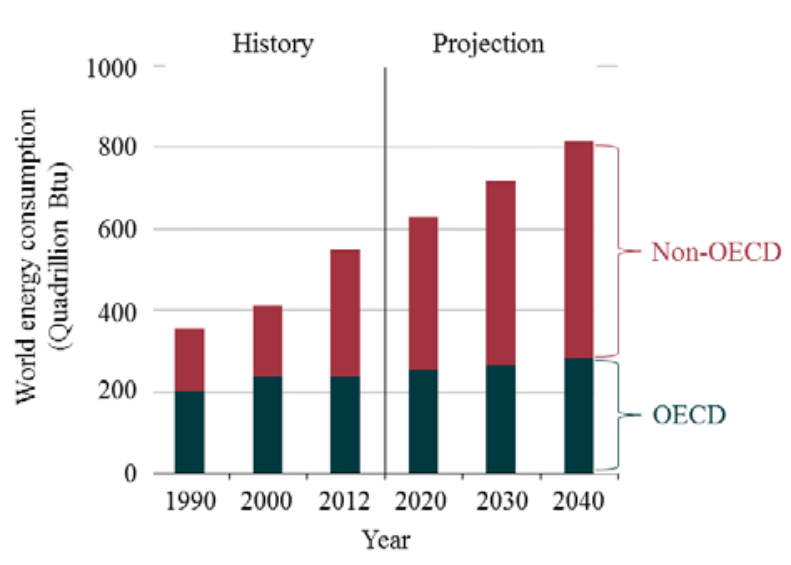

Fig. 2: World energy consumption from 1990 to 2040(Estimated) ${ }^{2}$ Source: U.S. Energy Information Administration (May Oct 2016)

\section{Hydrogen Society}

These days, the usage of hydrogen as energy carrier has attracted attention because it is good at storing huge amount of energy. Combination of solar/wind energy and hydrogen can be a bright candidate to establish sustainable society because they can be combined as a closed energy cycle with water and hydrogen (,and oxygen in air). ${ }^{7}$ Fig. 3 shows schematic system of society combined with fuel cells, water electrolyzers and renewable energy. This system is called "Hydrogen Society", which is completely dependent on consumption of fossil fuels to obtain electricity.

However, the hydrogen itself currently has to be isolated or produced from other chemical compounds such as carbon hydride $\left(\mathrm{C}_{\mathrm{x}} \mathrm{H}_{\mathrm{y}}\right)$. It is because producing hydrogen with water electrolyzers is much more expensive than fuel reforming with fossil fuels. ${ }^{8}$ The amount of production of fossil fuels will begin to phase out after the production peak explained in introduction part. The system in Fig. 3 to be substituted for our conventional energy supply with fossil fuels will be necessary. In fact, this system has already begun to be adopted to produce hydrogen by electrolyzing water to realize a sustainable society ${ }^{9,10}$. Recently, renewable energy markets, technologies, investment and policy frameworks have been rapidly developed. The ratio of global energy supplied by renewable energy in 2010 was $16.7 \%$. The consumption has strongly increased year by year ${ }^{11}$. However, there are remaining issues for widespread utilization of renewable energy sources. For instance, the installation cost is expensive, and the amount of hydrogen which can be stored at a time is small. To overcome both issues, the success depends on the result of research and development. Especially, Japanese government has established the

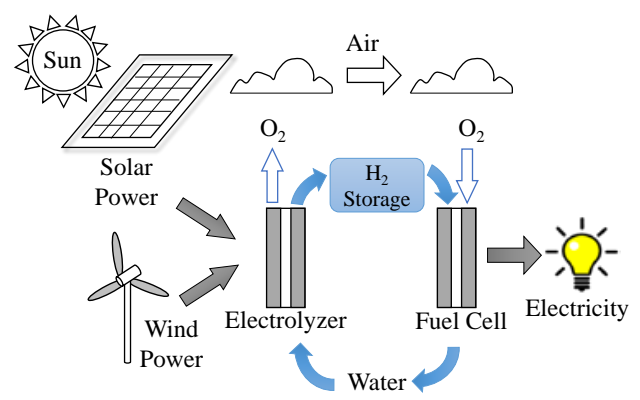

Fig.1 Concept of a hydrogen renewable energy system for power generation

(This system is independent on consumption of fossil fuel)

Fig. 3: Schematic model of hydrogen society. ${ }^{12,13}$

\section{Roadmap for Hydrogen Society in Japan}

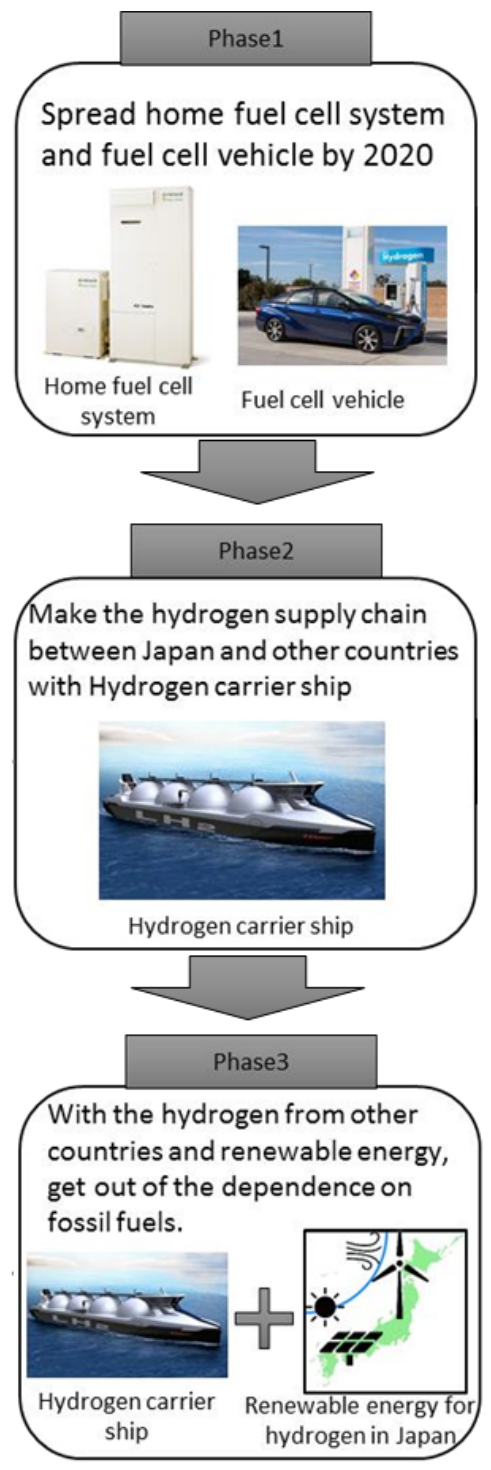

Fig. 4: Three phases to get out of dependence on fossil fuels in Japan ${ }^{14}$ 
To get out of dependence on the fossil fuels, Japan has energy policy to build hydrogen society as shown in Fig 3. It is composed of three phases as shown in Fig 4. Firstly, it is to spread home-type fuel cell and fuel cell vehicle by 2020. Secondary, it is to make the hydrogen supply chain between Japan and other countries with unused hydrogen by 2030 . Finally, with the supply chain and hydrogen from renewable energy, Japan will aim to get out of dependence on the fossil fuels by $2040{ }^{14}$. The above plan is really challenging because Japanese government also attempts to cover around $20 \%$ electricity of Japan by 2030 with renewable energy. In short, still Japan will provide $80 \%$ electricity with fossil fuels until 2020. If Japan follows above plan shown in Fig. 5, Japan will be required to cover entire electricity demand by 2040 with renewable energy in 10 years from 2030. Such a rapid installation of fossil fuels, it may lead to accelerate the consumption of fossil fuels and the amount of emitted harmful substances due to the fossil fuel consumption, which is called "Green Paradox".

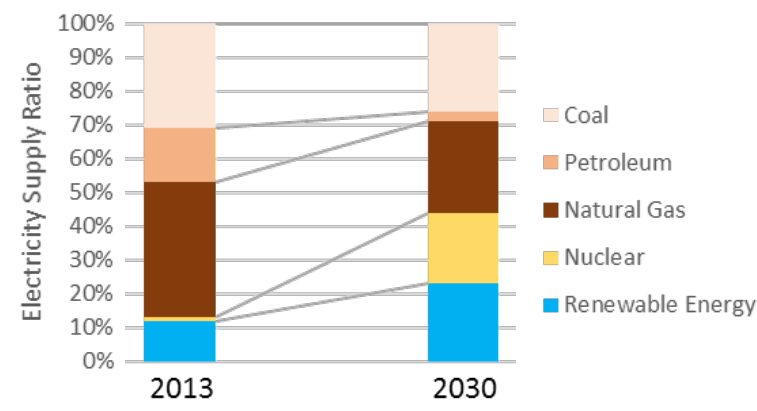

Fig. 5: The component ratio for electricity supply between 2013 and 2030(Target Value) ${ }^{15}$.

\section{Green Paradox}

According to Jensen et al., the green paradox refers to an outcome in which climate policies such as carbon taxes, which are aimed at reducing carbon emissions, instead have the opposite effect: emissions increase, at least for some period of time.”" Green paradox hypothesis comes to receive attention from 2008 when Sinn et. al.pointed out $^{17}$. Sinn et. al. suggest the mechanism that introducing renewable energy is likely to increase the amount of $\mathrm{CO}_{2}$ emission as follows. As shown in Fig. 6, in case that the price of electricity in both country A and country B, companies in respective countries will not be affected by the electricity price. However, when country A actively introduces renewable energy, the price in the country A will increase. Therefore, companies in Country A will relocate factories to Country B. Thus, introducing renewable energy in specific country such as this Country A induces to have factories which used to be in country A increase the amount of $\mathrm{CO}_{2}$ emission and shortage the term for minable years of fossil fuels in the world. This is the example of Green Paradox.

Because fossil fuels are finite, as long as we continue economic activity, the fossil fuels will be exhausted at some point in the future. Although we somehow need to seek the alternative energy resources and we have kept expecting renewable energy can be a promising, the Green Paradox suggests introduction of renewable energy does not have a positive effect. In addition, there is concern that people in the country where factories relocated are confronted with employment issue. What above Green Paradox insists is that introduction of renewable energy is not the suitable solution to reduce dependence on fossil fuels.

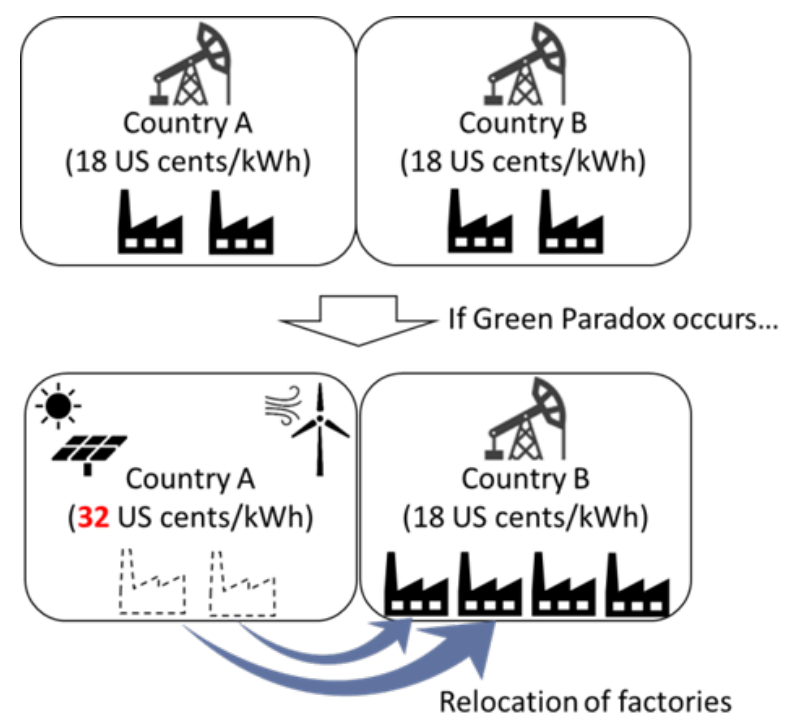

Fig. 6: The result of Green Paradox between Country A and Country B.

\section{Literature Review}

Before evaluation of the Green Paradox in Japan, this paper summarizes previous studies. As mentioned, the previous studies pointed out the cases consisting with Green Paradox hypothesis. In case of Ghana, previous research addressed the possibility that assumption of Green Paradox was realized. After refined oil subsidies finished from 2010, the import cost of oil rises. The result shows that the removal of subsidies on refined oil imports in Ghana would lead to the increase of $\mathrm{CO}_{2}$ emissions in Ghana. This is an evidence of the Green Paradox. ${ }^{18}$ In addition, in case of China, previous research addressed that the policy of central government prevents Green paradox, but that of local government does not prevent it. The previous research compares the emission of $\mathrm{SO}_{2}$ to evaluate the amount of $\mathrm{CO}_{2}$ emmision ${ }^{19}$. Furthermore, another research implies that Germany also occurs because the country increased the price of electricity to 
introduce renewable energy ${ }^{20}$. However, evaluation methods to clarify if Green Paradox occurs are not in common and unclear in several points. Therefore, in order to clarify Green Paradox in Japan, it is necessary to needs to establish advanced and sophisticated evaluation method.

\section{Evaluation Method}

Just a few reports related to the investigation of Green Paradox in each country have been published. Then, to examine whether Green Paradox occurs in Japan, this section explains the evaluation procedure for Green Paradox in Japan. As mentioned above, the Green Paradox refers to that introducing renewable energy eventually leads to increase the amount of harmful substances emission due to expensive electricity price and relocation of factories. This study collected following there types of data between 1996 and 2015 in Japan. The first is the amount of electricity price, the second is the renewable energy ratio in total electricity production, and the third is the trend in overseas production. All data obtained from Ministry of Economy, Trade and Industry, and Ministry of Land, Infrastructure, Transport and Tourism in $\operatorname{Japan}^{20,21,22}$.

\section{Results and Discussion}

Table.1 summarizes the data for the amounts of electricity price, renewable energy ratio in total electricity production, and the trend in overseas production. Some data are missing because of lack of original data. It is considered that renewable energy introduction leads to electricity price, whose change cause eventually to move factories in Japan to move to other countries. From this analysis when the values of all indices increase in same year, it is seemed that Green Paradox occurs in Japan.

Fig. 7 shows the graphical data of summarized table1. In the three terms shown by red band (1996, 1999, and between 2012 and 2014) the price of electricity, ratio of renewable energy, and trends in overseas production ratio increased, suggesting that the Green Paradox may occur in Japan in that above three terms ${ }^{20,21,22}$.

Because renewable energy is higher cost than conventional primary energy, it is thought that the increase in the ratio of renewable energy causes a bad influence on electricity charges. In addition, some Japanese industries say that raising the electricity price can be considered as a cause of overseas relocation. Therefore, these are phenomena are matching to the green paradox. In addition to the factors mentioned above, there seems to be other factors that affect each of them, but it can be proposed as one criterion for determining the green paradox.
Table1. Summarized data of trends in overseas production ratio, price of electricity, and ratio of renewable energy in Japan.

\begin{tabular}{|c|c|c|c|}
\hline year & $\begin{array}{l}\text { Trends in } \\
\text { overseas } \\
\text { production } \\
\text { ratio (\%) }\end{array}$ & $\begin{array}{c}\text { Price of } \\
\text { Electricity } \\
\text { (JPY) }\end{array}$ & $\begin{array}{c}\text { Ratio of } \\
\text { Renewable } \\
\text { Energy (\%) }\end{array}$ \\
\hline 1965 & & & 0.109 \\
\hline 1966 & & & 0.109 \\
\hline 1967 & & & 0.112 \\
\hline 1968 & & & 0.123 \\
\hline 1969 & & & 0.132 \\
\hline 1970 & & 4.968 & 0.139 \\
\hline 1971 & & 5.089 & 0.143 \\
\hline 1972 & & 5.115 & 0.147 \\
\hline 1973 & & 5.328 & 0.156 \\
\hline 1974 & & 9.301 & 0.151 \\
\hline 1975 & & 10.276 & 0.145 \\
\hline 1976 & & 11.753 & 0.157 \\
\hline 1977 & & 12.955 & 0.159 \\
\hline 1978 & & 12.428 & 0.161 \\
\hline 1979 & & 13.114 & 0.179 \\
\hline 1980 & & 20.829 & 0.176 \\
\hline 1981 & & 21.295 & 0.176 \\
\hline 1982 & & 21.608 & 0.188 \\
\hline 1983 & & 21.586 & 0.201 \\
\hline 1984 & & 21.562 & 0.215 \\
\hline 1985 & & 21.908 & 0.221 \\
\hline 1986 & & 19.994 & 0.226 \\
\hline 1987 & & 18.695 & 0.238 \\
\hline 1988 & & 17.719 & 0.248 \\
\hline 1989 & & 17.152 & 0.260 \\
\hline 1990 & & 17.145 & 0.577 \\
\hline 1991 & & 17.327 & 0.582 \\
\hline 1992 & & 17.548 & 0.574 \\
\hline 1993 & & 17.536 & 0.570 \\
\hline 1994 & 7.907 & 17.134 & 0.584 \\
\hline 1995 & 8.259 & 16.943 & 0.612 \\
\hline 1996 & 10.403 & 16.503 & 0.622 \\
\hline
\end{tabular}




\begin{tabular}{cccc}
1997 & 11.049 & 16.749 & 0.634 \\
1998 & 11.589 & 15.895 & 0.598 \\
1999 & 11.393 & 15.468 & 0.613 \\
\hline 2000 & 11.781 & 15.443 & 0.623 \\
2001 & 14.319 & 15.457 & 0.609 \\
2002 & 14.604 & 14.392 & 0.622 \\
2003 & 15.579 & 14.075 & 0.641 \\
2004 & 16.219 & 13.754 & 0.637 \\
2005 & 16.734 & 13.512 & 0.674 \\
2006 & 18.123 & 13.618 & 0.723 \\
2007 & 19.055 & 13.655 & 0.679 \\
2008 & 17.004 & 15.215 & 0.626 \\
2009 & 17.041 & 13.768 & 0.613 \\
2010 & 18.132 & 13.646 & 0.944 \\
\hline 2011 & 18.004 & 14.592 & 0.960 \\
2012 & 20.290 & 15.727 & 0.891 \\
2013 & 22.889 & 17.525 & 0.916 \\
2014 & 24.255 & 18.864 & 0.944 \\
2015 & & & 0.970 \\
\hline
\end{tabular}

criteria to determine if the Green Paradox occurs in specific country. Form the viewpoints of electricity rates, introduction of renewable energy, overseas production ratio, Japan is also determined that Green Paradox occurred 3 times in 1996, 1999, and between 2012 and 2014.

\section{Acknowledgements}

This research was supported by advanced graduate program in global strategy for Green Asia of JSPS.

\section{References}

1) International Energy Agency (IEA): Key world energy Statistics (2015).

2) Energy Information Administration, International Energy Outlook 2016, U.S. Department of Energy, May 2016.

3) BP Statistical Review, June 2016.

4) Mohr, S., Wang, J., Ellem, G., Ward, J. \& Giurco, D., "Projection of world fossil fuels by country", Fuel, 141, pp. 120-135 (2015).

5) Karl, T.R., Arguez, A., Huang, B., Lawrimore, J.H., McMahon, J.R., Menne, M.J., Peterson, T.C., Vose, R.S. \& Zhang, H.M., "CLIMATE CHANGE. Possible artifacts of data biases in the recent global surface warming hiatus", Science, 348(6242), pp. 1469-1472 (2015).

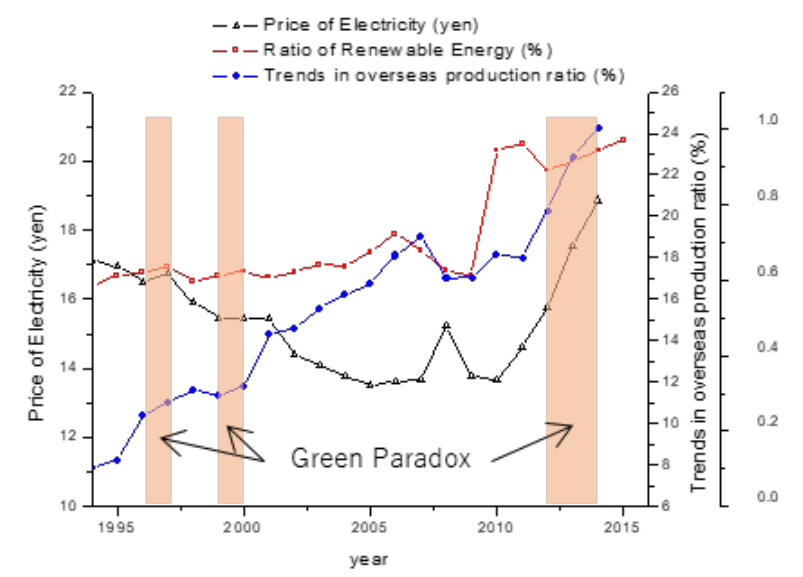

Fig. 7: Changes in electricity rates, introduction of renewable energy, overseas production ratio as function of year in Japan. Pale pink means the term that price of electricity, ratio of electricity, and trends in overseas production ratio increased simultaneously.

\section{Conclusion}

This study summarized previous paper evaluating several countries for the Green Paradox, and showed that there is no unified criteria to evaluate whether the Green Paradox occurs, or not. Then, this paper suggested novel

6) Zarfl, C., Lumsdon, A.E., Berlekamp, J., Tydecks, L. \& Tockner, K., "A global boom in hydropower dam construction", Aquatic Sciences, 77(1), pp. 161-170 (2015).

7) Wang, C. \& Nehrir, M.H., "Power management of a stand-alone wind/photovoltaic/fuel cell energy system", IEEE Transactions on Energy Conversion, 23(3), pp. 957-967 (2008).

8) Elam, C.C., Padró, C.E.G., Sandrock, G., Luzzi, A., Lindblad, P. \& Hagen, E.F., "Realizing the hydrogen future: the International Energy Agency's efforts to advance hydrogen energy technologies", International Journal of Hydrogen Energy, 28(6), pp. 601607 (2003).

9) Cetin, E., Yilanci, A., Oner, Y., Colak, M., Kasikci, I. \& Ozturk, H.K., "Electrical analysis of a hybrid photovoltaic-hydrogen/fuel cell energy system in Denizli, Turkey", Energy and Buildings, 41(9), pp. 975-981 (2009).

10) Yilanci, A., Dincer, I. \& Ozturk, H., "A review on solar-hydrogen/fuel cell hybrid energy systems for stationary applications", Progress in Energy and Combustion Science, 35(3), pp. 231-244 (2009).

11) F. Orecchini, "The era of the energy vectors", 
International Journal of Hydrogen Energy, 14(31), pp. 1951-1954 (2006).

12) Mori, D., \& Hirose, K.. "Recent challenges of hydrogen storage technologies for fuel cell vehicles", International journal of hydrogen energy", 34(10), pp. 4569-4574 (2009).

13) O'hayre, R., Cha, S., Prinz, F.B. \& Colella, W., Fuel cell fundamentals, John Wiley \& Sons. p.22 (2016).

14) Ministry of Economy, Trade and Industry of Japan "Points of reservation for roadmap of hydrogen and fuel cell strategy"

(http://www.meti.go.jp/committee/kenkyukai/energy /nenryodenchi_fukyu/pdf/002_01_00.pdf) (Access: March 31. 2017)

15) Ministry of Economy, Trade and Industry of Japan, "Reform of policy for encouraging to introduce renewable energy"

( http://www.enecho.meti.go.jp/category/saving_and_ new/saiene/kaitori/dl/kaisei/0628tokyo.pdf) (Access: March 31. 2017)

16) Jensen, S., Mohlin, K., Pittel, K., \& Sterner, T.. “An introduction to the Green Paradox: The unintended consequences of climate policies". Review of Environmental Economics and Policy, 9(2), pp.246265 (2015).

17) Sinn, H.W., "The green paradox”, CESifo forum (Vol. 10, No. 3, p. 10), 2009 October, Institut für Wirtschaftsforschung.

18) Wesseh, Presley K., Boqiang Lin, and Philip Atsagli.(2016). "Environmental and welfare assessment of fossil-fuels subsidies removal: A computable general equilibrium analysis for Ghana." Energy 116 (2016): 1172-1179.

19) Zhang, Kun, Zong-Yong Zhang, and Qiao-Mei Liang. "An empirical analysis of the green paradox in China: From the perspective of fiscal decentralization." Energy Policy 103, pp. 203-211 (2017).

20) Agency for Natural Resources and Energy "Section 4: Trends in Secondary Energy"

( http://www.enecho.meti.go.jp/about/whitepaper/2016 html/2-1-4.html) (Access: May 19. 2018)

21) Ministry of Land, Information, Transport and Tourism "Trend of Overseas Production Ratio (Manufacturing Industry)"

( http://www.mlit.go.jp/hakusyo/mlit/h27/hakusho/h28 /html/n1113000.html） （Access: May 19. 2018）

22) Agency for Natural Resources and Energy "Electricity price change"

( http://www.enecho.meti.go.jp/about/whitepaper/2016
html/2-1-4.html）（Access: May 19. 2018） 